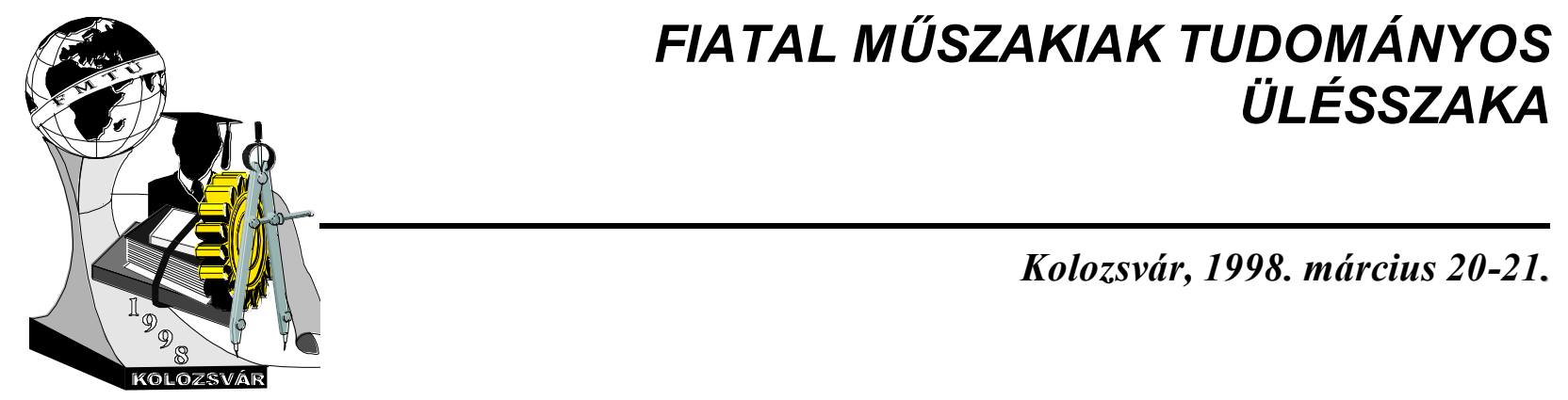

\title{
ÚJ NEMESFÉMHENGERLÉSI TECHNOLÓGIA ALAPJAINAK ÖSSZEFOGLALÁSA
}

\author{
STEIN GÁBOR \\ Ph.D. hallgató
}

The Hungarian accession to the European Union raises the question of the problem of size-economics in the precious metal industry and the revise of the future of this industry, as well. We can find out from the comparison of the value of taxes and customs of our neighborhood countries, that Hungary has to focus its forces to the manufacturing of products, based on pure metal base material, because of it's lack of own base of row materials. That is why a new base material and a new production technology intermediate products of which might yield significant save of costs, under more favorable quality parameters and conditions, might result in advantages in the market. The changing of direction of rolling has a significant impact on the mechanical properties of precious metal alloys, especially on the hardness, resulted by the effect of shaping. The result of experiments with different kind of alloys proved the same, so the conditions of applications are broaden of the new rolling technology, which considers the rolling direction, as well. With this new rolling technology we can not just adjust hardness of rolled wire more precisely, but it yields significant save of costs, as well.

\section{Bevezetés}

Mint minden iparágat, a nemesfémkohászatot is nagymértékben befolyásolja az anyaországban és a környező országokban alkalmazott gazdaságpolitikai eszköztár rendszere. Az erősödő versenyhelyzet, Európai Unióhoz való csatlakozásunk azt követeli meg a gyártóktól, hogy színfémekből kiindulva minél kisebb költséggel állítsák elö termékeiket. Mindezek figyelembevételével egy olyan új hengerlési technológia kidolgozását kell megvalósítani, mely segítségével nemcsak a legszigorúbb minőségi feltételeket lehet teljesíteni, hanem jelentős költségmegtakarítással is jár.

Nemesfém huzalok gyártásánál az igen szigorú méretpontossági követelmények mellett a darab mechanikai tulajdonságait is elöírják, például a szakítószilárdságot vagy a keménységet. (A World Gold Counsil adatai alapján egyre nagyobb kereslet mutatkozik a nagyszilárdságú nemesfémhuzalok iránt.) Egy nemesfémipari társaság mühelyi tapasztalata szerint kaliberhengerlésnél az alakítás irányának változtatása a 
nemesfémötvözetek alakíthatósági és mechanikai tulajdonságait jelentősen befolyásolja. Az összefüggések megkeresése érdekében egy méréssorozatot állítottam össze.

\section{A méréssorozat leírása}

Az első esetben a darabokat mindig azonos szálvéggel vezettem be a kaliberhengerek közé, második esetben pedig váltogatott szálvégü hengerlést valósítottam meg. Mindkén esetben az egyes szárások között a darabot $90^{\circ}$-kal elforgattam. Mintát 5-10\% -os alakváltozásonként vettem. A továbbiakban a mechanikai tulajdonságok közül a alakítás hatására bekövetkező keményedés összefüggéseit vizsgálom. A hengerlési irányra merőleges keres丸tmetszeten a keménységmérési helyek 1,2,..,9 az 1.ábrán láthatók.

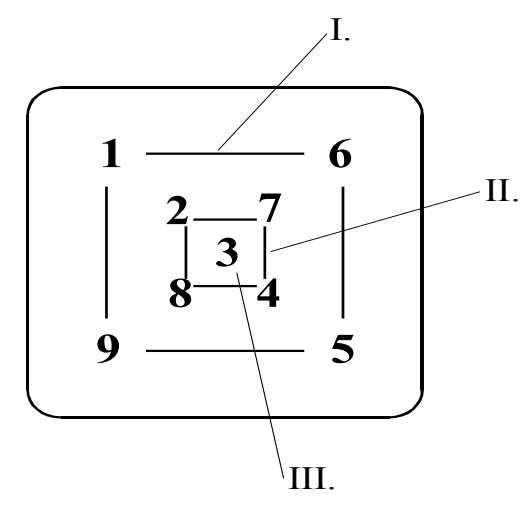

1. ábra: Keménységmérési helyek és térrészek a próbadarabokon

A keresłmetszet átlagos keménységét az I, II; III jelzésủ területrészek keménységének átlaga jelenti.

\section{A váltogatott irányú hengerlés hatása az alakithatóságra}

A mérési eredmények szerint a hengerlési irány váltogatásának kedvező hatása van az anyag alakíthatósági tulajdonságaira. A nagy összalakváltozások eredményeként létrejövő keresztirányú repedések, melyek létrejöttét a hengerüregek elhasználódása is elösegítette, váltogatott irányú hengerlésnél - az egyirányban végzett hengerléshez képest- nagyságrendileg körülbelül $10 \%$-kal nagyobb összalakváltozás mellett jelennek meg.

\section{Hengerelt huzal keménységének pontos és gazdaságos beállitása}

A 3-5. ábrák a korábban már definiált keménységmérési helyek $\mathrm{HV}_{5}$ keménységének változását mutatják az alakváltozás mértékének a függvényében. Az ábrákon található felíratok jelentése:

- 0 = egy olaszországi kísérlet eredménye, mely során az ellentétes irányú hengerlés hatását vizsgáltuk

- 1 a mindvégig egyirányban hengerelt huzal

- 2 = az egymás utáni szúrásokban minden egyes esetben megfordított darabot jelenti, ellentétes irányú hengerlés. 
$\mathrm{Az}$ egyirányban alakított huzal keménységi karakterisztikája (3 -5. ábrák) a 2.ábrán látható $\mathrm{AgCu}$ ötvözetekkel azonos jelleget mutat még akkor is, ha figyelembe vesszük a kétféle keménységmérési jelzőszám számszerü eltéréséből eredő különbségeket. Az alakítás mértékének növekedésével kezdetben növekvő keménységnek kb. 30 \% -os alakváltozás után egy kevésbé meredek szakasza következik, mely megközelítőleg 50 \% -os alakváltozás után ismét jelentősen növekvő függvénnyé válik. A váltogatott irányban hengerelt darabok keményedési görbéi jellegüket tekintve sem mutatnak hasonlóságot csak abban, hogy monoton növekvő függvények. Az ellentétes irányban hengerelt huzalok keménysége a kisebb alakváltozási tartományban, mely megközelítőleg $20 \%$-os alakváltozásig tart, sokkal erőteljesebb ütemben növekszik, mint az egyirányban hengerelt daraboké, ám e határérték után keménységük csak igen kis mértékben növekszik tovább. A két, váltogatott irányban hengerelt méréssorozat abban különbözik egymástól, hogy a $\boldsymbol{0}$. jelzésű méréssorozatban a hengerlési sebesség nagyobb volt. A keresztmetszetek különböző térrészeinél jól kitünik, hogy azonos összalakváltozások esetén nagyobb hengerlési sebességhez kisebb keménység tartozik. A váltogatott irányba hengerelt huzal keménységgörbéinek meredeksége, a különböző hengerlési sebességeket tekintve, gyakorlatilag azonos, ezért a görbék jó közelítéssel egymás párhuzamos eltolásával származtathatók. A különböző módon alakított darabok keménysége, a keményedési görbék alakja és meredeksége viszont az összalakváltozás függvényében jelentős eltérést mutat. E különbség azt eredményezi, hogy e görbéknek metszeniük kell egymást.

A 3-5. ábrákon jól látható, hogy a váltogatott irányba hengerelt huzalok keménysége tág határok között alig változik az alakítás mértékének a függvényében. A 30 - 70\% -os összalakváltozások közötti keménységnövekedés az Ag935Cu jelü ötvözetnél például 20\% alatt van. Az Ag935Cu jelü ötvözetnél a váltogatott irányban hengerelt huzal keménységének változása -30 - 70\% -os összalakváltozások közöttkevesebb, mint $50 \%$-a a mindvégig egyirányban hengerelt huzalénak. Az abszolút keménységértékeket is figyelembe véve, ha a $30 \%$-os összalakváltozáshoz tartozó keménységet vesszük alapul, a váltogatott irányban végzett további alakítás, összalakváltozásban mérve, mindössze $10 \%$-nál kisebb keménységnövekedést idézett elő.

\section{Következtetések}

A keménységet pontosan és gazdasági szempontból is hatékonyan kell beállítani. Erre, tehát a keménység - alakítás mértéke által meghatározott területrész tetszőleges pontjának elérésére, több lehetőség van:

1. A hengerlési sebességet állandónak véve a különböző irányban végzett hengerlési technológiákat úgy kombináljuk, hogy a kívánt keménységet elérjük. A minél pontosabb beállítás érdekében célszerü a végső szakaszban a kisebb keményedési meredekséggel rendelkező váltogatott irányú hengerléssel előállítani a készterméket, illetve beállítani a kívánt keménységet. 
2. Ha az alakváltozás mértéke nem változtatható tág határok között, például a közbenső hőkezelések eloszlása miatt, akkor a hengerlési sebesség és a különböző irányú hengerlési technológiák megfelelő megválasztásával lehet beállítani a méretet és a keménységet.

Ezen paraméterek pontos meghatározására természetesen az eddig elvégzett kísérleteknél még nagyobb számú mérés szükséges.

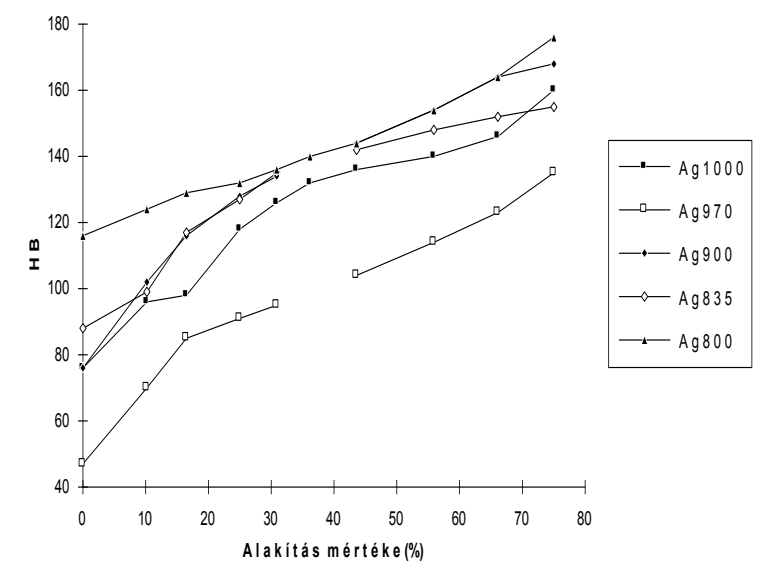

2. ábra: Ag-Cu ötvözetek keménysége

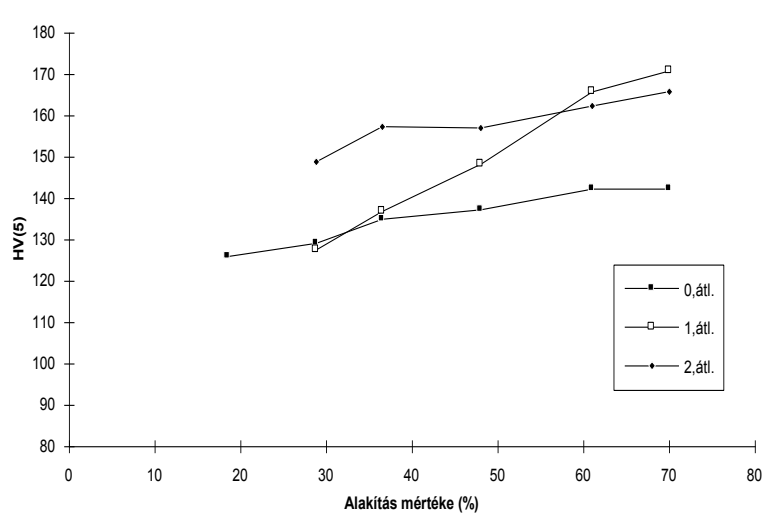

3. ábra $\mathrm{Az} \mathrm{Ag935Cu} \mathrm{jelü} \mathrm{ötvözet}$ átlagos (átl.) keménysége

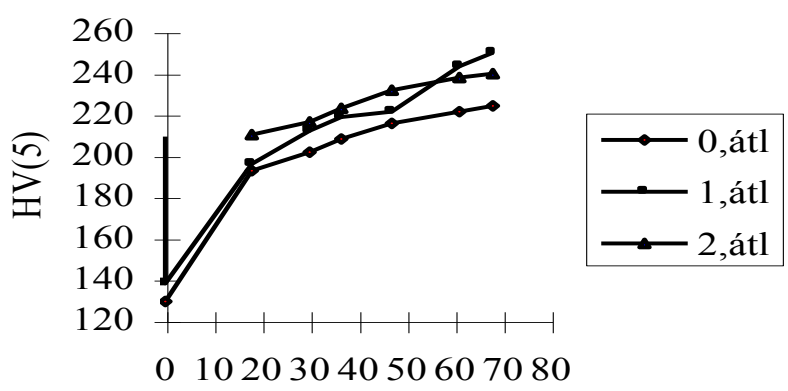

Alakítás mértéke (\%)

4. ábra Az fAg27Ni jelű ötvözet átlagos (átl.) keménysége

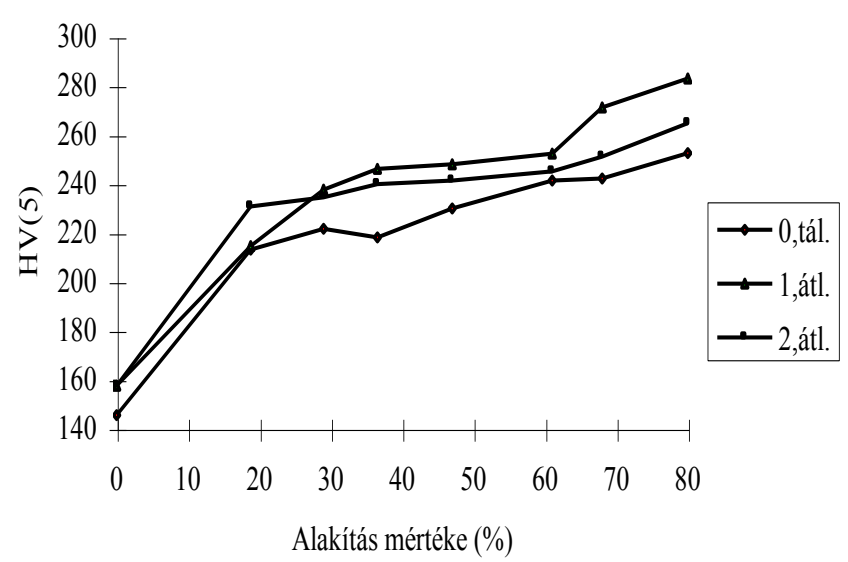

5. ábra Az fAg49Ni jelű ötvözet átlagos (átl.) keménysége

\section{Stein Gábor}

Miskolci Egyetem, Regionális Gazdaságtan Tanszék

3515 Miskolc-Egyetemváros

Tel.: +36 46-365-111/20-51

Fax: +36 46-367-865 